Article

\title{
Effects of Particle Size on Diffusion Kinetics in Chinese Anthracites during $\mathrm{CH}_{4}$ Desorption
}

\author{
Jie Zang ${ }^{1,2,3,4, *}$, Kai Wang ${ }^{1,3}$ and Yanbin $\mathrm{Yu}^{4, *}$ \\ 1 Faculty of Emergency Management and Safety Engineering, China University of Mining and Technology, \\ Beijing 100083, China; kaiwang@cumtb.edu.cn \\ 2 State Key Laboratory Cultivation Base for Gas Geology and Gas Control, Jiaozuo 454150, China \\ 3 Beijing Key Laboratory for Precise Mining of Intergrown Energy and Resources, \\ China University of Mining and Technology, Beijing 100083, China \\ 4 Key Laboratory of Mining Disaster Prevention and Control, Qingdao 266590, China \\ * Correspondence: jiezang@cumtb.edu.cn (J.Z.); yanbinyu@sdust.edu.cn (Y.Y.)
}

Received: 2 March 2020; Accepted: 12 April 2020; Published: 27 April 2020

\begin{abstract}
Diffusion kinetics is widely acknowledged to dominate gas flow in coal matrix blocks. Knowledge of this topic is important for ongoing coalbed methane recovery and $\mathrm{CO}_{2}$-enhanced coalbed methane production. Because laboratory diffusivity measurements are normally conducted on powdered coals, it is unclear how representative the results are for coalbeds. Investigations into the effects of particle size on gas diffusivity can provide insights into the in situ diffusivity of the coal matrix. This paper presents measured $\mathrm{CH}_{4}$ desorption data in two Chinese anthracites (one brittle, one hard) having different particle sizes, to investigate the effects of particle size on diffusion kinetics. The experimental data were fitted by both the unipore (UP) and bidisperse (BD) models. The BD model agreed better with the measured data than the UP model, especially for the brittle coal. This indicated that the brittle coal was more abundant in macropores than the hard coal. Diffusivity in the hard coal decreased with increasing particle size but varied stochastically within a small value range in the brittle coal as the particle size increased. The diffusivity of the brittle coal, with its higher vitrinite content and lower inertinite content, was greater compared with the hard coal. This was inconsistent with reported data in which vitrinite had a smaller diffusivity than inertinite. This anomalous phenomenon may be caused by the generation of comparatively more macropores during grinding in the brittle coal. These results indicate that the effects of particle size on diffusivity may be coal-dependent, and further, the effects of particle size are influenced by other factors, including coal structure.
\end{abstract}

Keywords: desorption; diffusion kinetics; particle size; Chinese anthracite

\section{Introduction}

Due to the ongoing development of coalbed methane (CBM) recovery, carbon dioxide enhanced coalbed methane $\left(\mathrm{CO}_{2}\right.$-ECBM) production, and $\mathrm{CO}_{2}$ storage in coalbeds, detailed and reliable information on gas sorption in coals is required [1]. However, the concerns are different for each project. For CBM recovery, it is necessary to know the methane $\left(\mathrm{CH}_{4}\right)$ content in coal to determine the gas reserves in coalbeds [2,3]. For pure $\mathrm{CO}_{2}$ sequestration, the sorption capacity of coals is important $[1,4]$. As for the $\mathrm{CO}_{2}$-ECBM process, conditions are somewhat complicated because of the selective sorption behaviors of $\mathrm{CO}_{2}$ and $\mathrm{CH}_{4}$ [5-7].

Apart from the gas sorption behavior, gas transport in coals is also significant, directly affecting production and injection efficiencies and determining the success of a project. Gas flow in coals is normally considered to occur in two stages: laminar flow in the cleat system and diffusion in the coal 
matrix $[1,8]$. This paper focuses on $\mathrm{CH}_{4}$ desorption kinetics, and therefore laminar flow will not be discussed; this topic is considered elsewhere $[9,10]$.

Gas diffusion is normally modeled by two methods, the so-called unipore (UP) model and the bidisperse (BD) model. The UP model assumes a uniform pore structure in coal matrix blocks [11], while the BD model envisages that the coal matrix contains two distinct pore systems (micropores and macropores) [12]. For the UP model, only one diffusivity value is considered. However, for the BD model, the value in each pore system should be taken into account, i.e., the macropore and micropore diffusivities $[12,13]$. Many researchers have investigated the gas diffusion kinetics of coals using existing analytical models or self-developed numerical models. Gas diffusion kinetics has been investigated comprehensively on both wet and dry coals ranked from subbituminous to anthracite, obtained from various countries and regions including Australia, Canada, China, India, Indonesia, and America. These comprehensive results indicate that the gas diffusivity or sorption rate in coals varies in relation to coal rank $[4,8,14,15]$, gas pressure [5,13,16-20], particle size [21-25], moisture content $[13,16,20,22,23]$, and sorbate type [5,19,22-25].

Although diffusion kinetics evaluation for coal powders is convenient, the representative applicability of the results in actual coalbeds may be problematic [25]. Investigations on the effects of particle size on gas diffusivity can provide insight into the in situ diffusivity of the coal matrix. Marecka and Mianowski [21] investigated the gas sorption rate in a semi-anthracite coal with different grain-size fractions. They showed that the sorption rate decreased with increasing particle size. Similar results have been described elsewhere [22,23]. Bhowmik and Dutta [24] studied gas diffusion kinetics in Indian coals ranking from subbituminous to high-volatile bituminous, and reported that the diffusivity decreased with increasing particle size. However, diffusion kinetics modeling the results from Chinese anthracites described by Han et al. [25] revealed that the diffusivities of both $\mathrm{CH}_{4}$ and $\mathrm{CO}_{2}$ increased with particle size. The decrease in the diffusivity or sorption rate may have been due to the generation of additional macropores during grinding, which positively impacted diffusion [26]. However, Han et al. [25] attributed their anomalously increasing diffusivity with particle size to the heterogeneity of their samples and an improper estimation of the particle size. Additionally, it should be noted that there may be a critical particle diameter beyond which the diffusivity remains more or less invariant [27]. This is because, in larger particles, gas transport in the cleat system becomes dominant although the inter-cleat diffusion distances remain virtually constant [22].

The inconsistency in the aforementioned literature reports with respect to the effects of particle size and diffusivity indicates that the relationship between these properties may be coal-dependent. In this paper, we present diffusion kinetics results for two Chinese anthracites (one brittle, the other hard) having different particle sizes. $\mathrm{CH}_{4}$ desorption data were measured and diffusivity values were obtained by fitting the data to the UP and BD models._ENREF_16

\section{Sample Preparation}

The brittle and hard coal samples were obtained from the Jiulishan Coal Mine (JLS) and Zhaogu No. 2 Coal Mine (ZG) in Jiaozuo City, Henan Province, respectively. The air-dried coal lumps were pulverized and passed through sieves of different sizes. Three particle-size ranges were selected for subsequent experimental measurements: $0.2-0.25,0.5-1.0$, and $1.0-3.0 \mathrm{~mm}$. Note that the $-0.2 \mathrm{~mm}$ and $0.25-0.5 \mathrm{~mm}$ particles were similar to the $0.2-0.25 \mathrm{~mm}$ particles in dimension. Their diffusion kinetic behaviors may be similar to the behavior of the $0.2-0.25 \mathrm{~mm}$ particles. In order to make the influences of particle size on diffusion kinetics more distinguishable, the $-0.2 \mathrm{~mm}$ and $0.25-0.5 \mathrm{~mm}$ particles were not selected for the measurements in this study.

Coal properties (Table 1) were measured using the samples in the $0.2-0.25 \mathrm{~mm}$ particle size range. Note that particle size may have influences on coal properties but the influences are generally not remarkable. Moreover, this study does not focus on the influences of particle size on coal properties. The properties of $0.2-0.25 \mathrm{~mm}$ particles can represent the other two kinds of sample. 
Table 1. Properties of the Jiulishan Coal Mine (JLS) (brittle) and Zhaogu No. 2 Coal Mine (ZG) (hard) coal samples.

\begin{tabular}{|c|c|c|c|c|c|c|c|c|c|c|}
\hline \multirow{2}{*}{ Sample } & \multirow{2}{*}{$\begin{array}{l}\text { True Density } \\
\left(\mathrm{g} / \mathrm{cm}^{3}, \text { dry) }\right.\end{array}$} & \multicolumn{2}{|c|}{ Langmuir Constants } & \multicolumn{3}{|c|}{ Ultimate Analysis (\%) } & \multicolumn{4}{|c|}{ Petrographic Analysis (\%) } \\
\hline & & $\begin{array}{c}V_{L} \\
\left(\mathrm{~cm}^{3} / \mathrm{g}, \text { daf) }\right.\end{array}$ & $\begin{array}{c}P_{L} \\
\text { (MPa) }\end{array}$ & $M_{a d}$ & $A_{a d}$ & $V_{\text {daf }}$ & Vitrinite & Inertinite & Liptinite & $\begin{array}{l}\text { Mineral } \\
\text { Content }\end{array}$ \\
\hline JLS & 1.542 & 39.918 & 0.78 & 3.61 & 8.1 & 7.45 & 91.1 & 5.7 & - & 3.2 \\
\hline ZG & 1.703 & 52.945 & 0.94 & 2.2 & 7.63 & 8.45 & 82.7 & 16 & - & 1.3 \\
\hline
\end{tabular}

\section{Experimental Measurements}

Figure 1 shows a schematic of the experimental apparatus used in this study. This apparatus was established on the basis of the manometric sorption method. Both the sample and reference cells were immersed in a water bath for thermal regulation and to detect gas leakage. A drainage method was used for desorbed gas collection because $\mathrm{CH}_{4}$ is poorly soluble in water [13]. The temperature of the water tank was monitored in order to calculate the desorbed gas volume accurately.

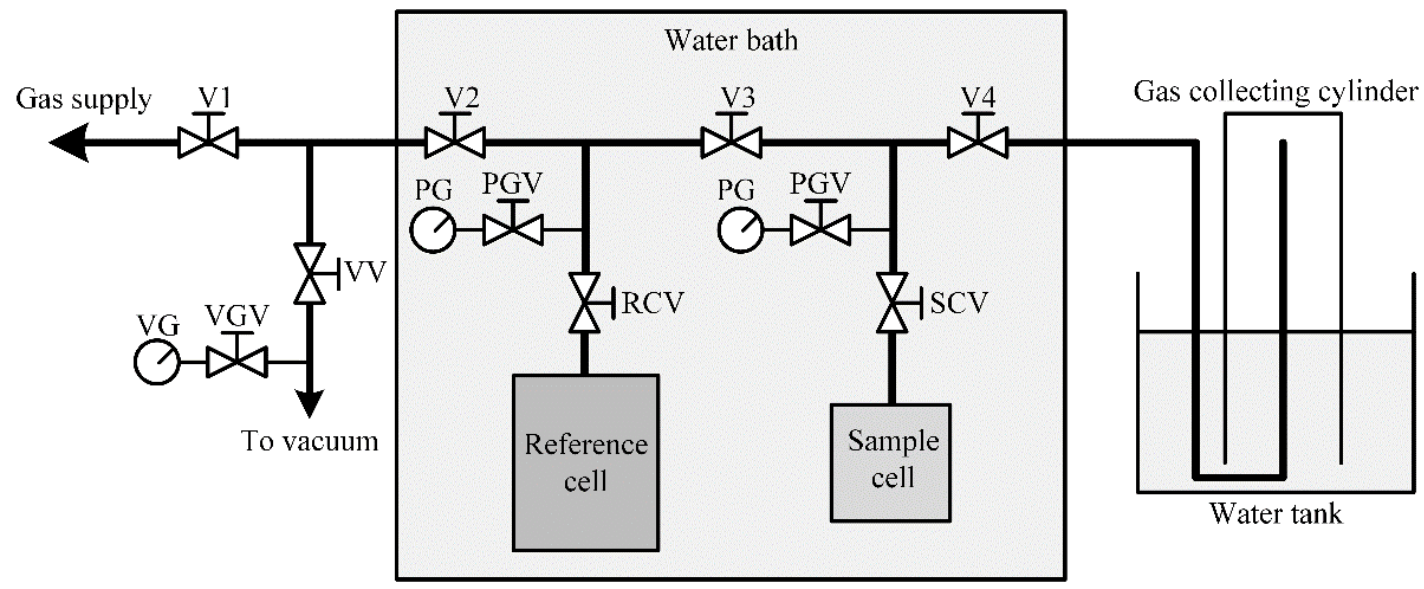

Figure 1. Schematic representation of the experimental apparatus [28]: V denotes the valve; PG is the pressure gauge; PGV is the pressure gauge valve; VG is the vacuum gauge; VGV is the vacuum gauge valve; $\mathrm{VV}$ is the vacuum valve; $\mathrm{RCV}$ is the reference cell valve; SCV denotes the sample cell valve.

The experimental procedures were controlled by the valves shown in Figure 1. The valve VV controlled the vacuum of the system. The valves V1, V2, and RCV controlled the injection of gas from gas cylinders to the reference cell. The valves RCV, V3, and SCV controlled the injection of gas from the reference cell to the sample cell. The valves SCV and V4 controlled the gas desorption procedure from the sample cell to the gas collecting cylinder.

A representative experiment for the $0.2-0.25 \mathrm{~mm}$ particle size sample is described below; the other sample sizes $(0.5-1.0$ and $1.0-3.0 \mathrm{~mm})$ were similarly evaluated:

(1) With an empty sample cell, detect the airtightness of the apparatus according to the method described in our previous study [28].

(2) When the apparatus is airtight, calibrate its void volume according to the previous method [28].

(3) Open the sample cell and fill it with the coal powder (130 g, 0.2-0.25 mm). Close the sample cell tightly.

(4) Heat a water bath to $303 \mathrm{~K}$ and hold constant.

(5) Detect the airtightness and calibrate the void volume of the apparatus again as previously described [28].

(6) Close V1 and V4. Open V2, V3, RCV, SCV, and VV. Evacuate the apparatus with a vacuum pump. After the VG recording remains invariant for $2 \mathrm{~h}$, close VV. 
(7) Close V3. Open V1 and slowly inject $\mathrm{CH}_{4}$ gas from a gas cylinder into the reference cell. When the PG of the reference cell reaches $0.74 \mathrm{MPa}$, close $\mathrm{V} 2$ and terminate gas injection.

(8) Open V3 and release $\mathrm{CH}_{4}$ from the reference cell to the sample cell. When the coal powder in the sample cell reaches adsorption equilibrium, close V3.

(9) Repeat Steps (7) and (8) until the coal powder in the sample cell reaches adsorption equilibrium at a gas pressure of $0.74 \mathrm{MPa}$.

(10) Close V4 and open the valve between the sample cell and the gas collecting cylinder. Release the $\mathrm{CH}_{4}$ from the sample cell to the gas collecting cylinder and record the water volume change in the latter in the first $120 \mathrm{~min}$.

(11) Clean the sample cell and reload it with the $0.5-1.0 \mathrm{~mm}$ sample.

(12) Repeat Steps (3)-(10).

(13) Clean the sample cell and reload it with the 1.0-3.0 mm sample.

(14) Repeat Steps (3)-(10).

Note that this paper focuses on desorption kinetics, and so only the data within 120 min were measured. After $120 \mathrm{~min}, \mathrm{CH}_{4}$ gas can desorb from the sample cell but the amount was relatively small compared with the amount desorbed in the initial $120 \mathrm{~min}$. During 0-20 $\mathrm{min}$, the data were recorded at intervals of $1 \mathrm{~min}$. During 20-40, 40-60, and 60-120 $\mathrm{min}$ the recording intervals became 2, 5, and $10 \mathrm{~min}$, respectively.

\section{Representations of the UP and BD Models}

Physical meanings of all model parameters are shown in Nomenclature.

\subsection{UP Model}

The UP model is the analytical solution of Fick's second law (Equation (1)) in symmetrical spheres with uniform radii and smooth surfaces [11]. The representation of the UP model is shown in Equation (2).

$$
\begin{gathered}
\frac{\partial C}{\partial t}=\frac{1}{R^{2}}\left(D_{u} r^{2} \frac{\partial C}{\partial r}\right), \\
\left\{\begin{array}{c}
\frac{M_{t}}{M_{\infty}}=1-\frac{6}{\pi^{2}} \sum_{n=1}^{\infty} \frac{1}{n^{2}} \exp \left(-D_{u}^{\prime} n^{2} \pi^{2} t\right) \\
D_{u}^{\prime}=\frac{D_{u}}{R^{2}}
\end{array}\right.
\end{gathered}
$$

Equation (1) can be rewritten into the case of desorbed volume [20]

$$
\frac{V_{t}}{V_{\infty}}=1-\frac{6}{\pi^{2}} \sum_{n=1}^{\infty} \frac{1}{n^{2}} \exp \left(-D_{u}^{\prime} n^{2} \pi^{2} t\right) .
$$

\subsection{BD Model}

The UP model has been reported to fail in modeling gas diffusion in some low-rank coals, and the BD model may be more suitable for diffusion kinetics modeling in such coals $[8,17,20,29]$. Ruckenstein et al. [12] developed the BD model (Equation (6)) by assuming a spherical macroporous sphere consisting of small spherical microporous particles with uniform radius. The BD model is the solution of Equations (4) and (5), based on the assumptions of constant macropore and micropore diffusion coefficients, invariant surface sorbate concentration, and a linear isotherm [12].

$$
\phi_{a} \frac{\partial C_{a}}{\partial t}+S_{a} \frac{\partial C_{s a}}{\partial t}+\left.4 \pi n R_{i}^{2} D_{i} \phi_{i} \frac{\partial C_{i}}{\partial r_{i}}\right|_{r_{i}=R_{i}}=\frac{D_{a} \phi_{a}}{R_{a}^{2}} \frac{\partial}{\partial r_{a}}\left(r_{a}^{2} \frac{\partial C_{a}}{\partial r_{a}}\right)
$$




$$
\begin{gathered}
\phi_{i} \frac{\partial C_{i}}{\partial t}+S_{i} \frac{\partial C_{s i}}{\partial t}=\frac{D_{i} \phi_{i}}{R_{i}^{2}} \frac{\partial}{\partial r_{i}}\left(r_{i}^{2} \frac{\partial C_{i}}{\partial r_{i}}\right) \\
\left\{\begin{array}{l}
\sum_{r=1}^{\infty} \sum_{s=1}^{\infty} \frac{r^{2}\left[1-\exp \left(-\alpha \xi_{r s}^{2} D_{a}^{t} t\right)\right]}{\xi_{r s}^{4}\left[1+\frac{\alpha}{\beta}+\cot ^{2} \xi_{r s}-\left(1-\frac{r^{2} \pi^{2}}{\beta}\right) \frac{1}{\xi_{r s}^{2}}\right]} \\
\sum_{r=1}^{\infty} \sum_{s=1}^{\infty} \frac{r^{2}}{\xi_{\xi_{s}}^{4}\left[1+\frac{\alpha}{\beta}+\cot ^{2} \xi_{r s}-\left(1-\frac{r^{2} \pi^{2}}{\beta}\right) \frac{1}{\xi_{r s}^{2}}\right]} \\
\beta\left(1-\xi_{r s} \cot \xi_{r s}\right)+\alpha \xi_{r s}^{2}=r^{2} \pi^{2} k=1,2,3, \ldots, \infty \\
D_{a}^{\prime}=\frac{D_{a}}{R_{a}^{2}}\left(1+\frac{S_{a} H_{a}}{\phi_{a}}\right) \\
\alpha=\frac{D_{i}^{\prime}}{D_{a}^{\prime}}
\end{array}\right.
\end{gathered}
$$

Equation (6) can be reduced to a simplified form composed of a fast macropore diffusion stage and a much slower micropore diffusion stage [13]. The desorbed volume of the macropore diffusion stage can be represented by Equation (7) [12]:

$$
\frac{V_{a t}}{V_{a \infty}}=1-\frac{6}{\pi^{2}} \sum_{n=1}^{\infty} \frac{1}{n^{2}} \exp \left(-D_{a}^{\prime} n^{2} \pi^{2} t\right) .
$$

The desorbed volume of the micropore diffusion stage can be represented by Equation (8) [12]:

$$
\frac{V_{i t}}{V_{i \infty}}=1-\frac{6}{\pi^{2}} \sum_{n=1}^{\infty} \frac{1}{n^{2}} \exp \left(-D_{i}^{\prime} n^{2} \pi^{2} t\right) .
$$

The total desorbed volume of both macropores and micropores can be calculated via Equation (9) [13]:

$$
\frac{V_{t}}{V_{\infty}}=\frac{V_{a t}+V_{i t}}{V_{a \infty}+V_{i \infty}}=(1-\alpha) \frac{V_{a t}}{V_{a \infty}}+\alpha \frac{V_{i t}}{V_{i \infty}} .
$$

Substituting Equations (7) and (8) into Equation (9), the final BD model can be obtained. It should be noted that Equation (9) is slightly different from the original equation presented by Pan et al. [13], in which the ratio of the macropore sorption to the total sorption was used, but the two equations are essentially identical.

\section{Results}

The recorded desorption volumes were converted to those under normal temperature-pressure (NTP, 273.15 K and $101325 \mathrm{~Pa}$ ) conditions on a dry-ash-free (daf) basis in order to compare different data sets on the same standard. The desorbed volumes were converted according to the method described in our previous study [28].

Figure 2 presents the desorbed $\mathrm{CH}_{4}$ volumes measured in both JLS and ZG coals with different particle sizes. During the first $120 \mathrm{~min}$, the desorbed volumes of both coals decrease with increasing particle size. Within the same desorption time, $\mathrm{ZG}$ coal desorbs more $\mathrm{CH}_{4}$ than JLS coal. This is due to the higher adsorption capacity of ZG coal compared to JLS coal, as shown in Table 1. The desorbed volume from the JLS coal tends to plateau more quickly than that from the ZG coal. Because the two coals are of the same rank, this difference may be due to their different structures and maceral compositions, as will be discussed in the following sections. 
(a)
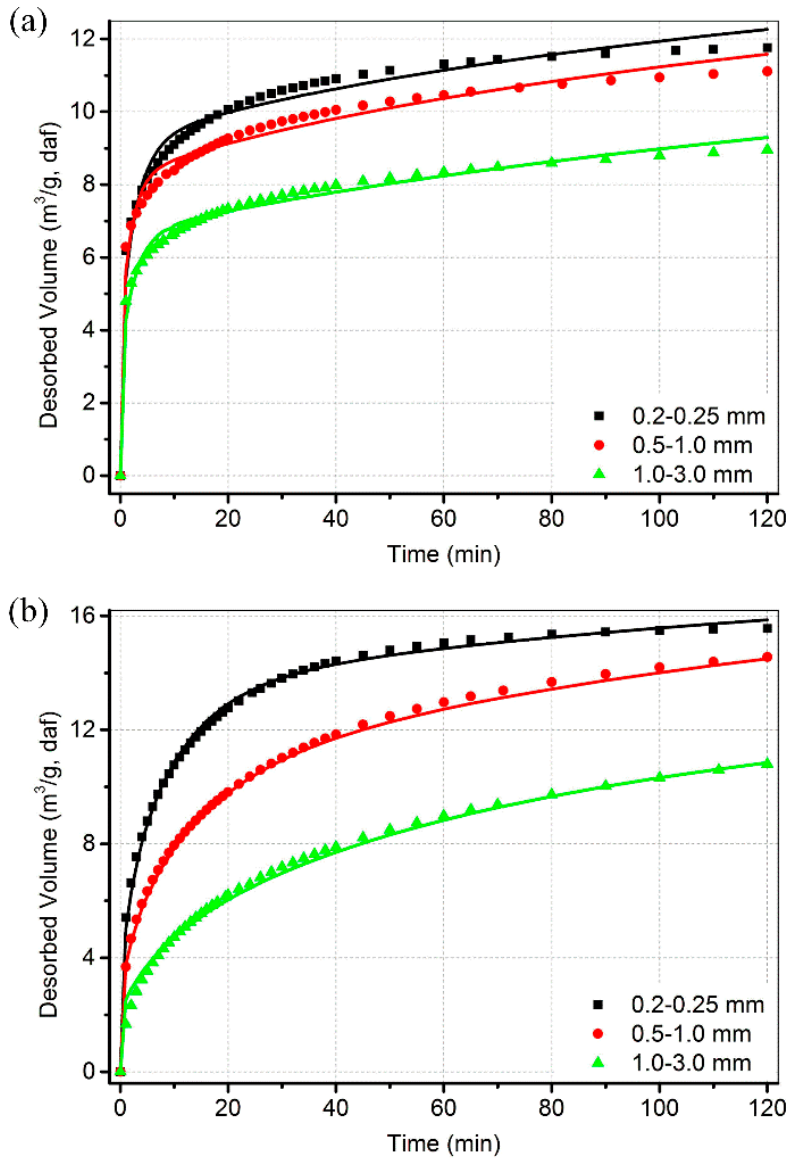

Figure 2. Experimental and modeling results for $\mathrm{CH}_{4}$ ) desorption: (a) JLS and (b) ZG. The solid boxes represent the experimental data and the solid line denotes modeling results from the bidisperse (BD) model.

Since the adsorbed volume was not measured, $V_{\infty}$ was calculated using the Langmuir constants presented in Table 1. In this paper, adsorption is assumed to be independent of particle size, so $V_{\infty}$ is

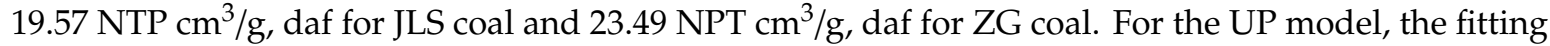
parameter is only $D_{e}$, whereas for the BD model, three are employed, $\alpha, D_{a e}$, and $D_{i e}$. Figure 2 shows the modeling results for the $\mathrm{BD}$ model. The modeling results from the UP model are not presented for either coal because of their significant deviations from the experimental data.

The BD model agrees much better with the experimental measurements than the UP model, as shown in Table 2. Because of the greater deviations of the UP model results from the experimental data, all analyses below are based on the BD model. As shown in Table 2, the relationship between diffusivity and particle size is different between the two coals. For JLS coal, the micropore diffusivity decreases with increasing particle size while the macropore diffusivity varies with particle size according to an inverse U-shaped function. As for ZG coal, both macropore and micropore diffusivity decrease with increasing particle size. Compared to ZG coal, the diffusivity of JLS coal is less affected by particle size. The diffusivity of ZG coal is always lower than that of JLS coal for the same size sample. This may be due to the hard structure of ZG coal compared to JLS coal, which has a brittle structure that may result in more grinding-induced fractures that favor diffusivity. The greater adsorption capacity of ZG coal compared to JLS coal may further contribute to the trend. The larger adsorbed volume occupies more pore space for diffusion, which reduces the diffusivity. The increasing $\alpha$ value for both coals indicates that the adsorption capacity in the micropores increases with particle size. This may be because larger particles contain fewer macropores [22]. 
Table 2. Modeling parameters for diffusion kinetics.

\begin{tabular}{|c|c|c|c|c|c|c|c|c|c|}
\hline \multirow{2}{*}{ Sample } & \multirow{2}{*}{$\begin{array}{l}\text { Particle Size } \\
(\mathrm{mm})\end{array}$} & \multicolumn{3}{|c|}{ UP Model } & \multicolumn{5}{|c|}{ BD Model } \\
\hline & & $V_{\infty}\left(\mathrm{cm}^{3} / \mathrm{g}\right)$ & $D_{u}^{\prime}\left(\mathrm{s}^{-1}\right)$ & $R^{2}(\%)$ & $V_{\infty}\left(\mathrm{cm}^{3} / \mathrm{g}\right)$ & $\alpha$ & $D_{a}^{\prime}\left(\mathrm{s}^{-1}\right)$ & $D_{i}^{\prime}\left(\mathrm{s}^{-1}\right)$ & $R^{2}(\%)$ \\
\hline \multirow{3}{*}{ JLS } & $0.2-0.25$ & 19.57 & $1.89 \times 10^{-5}$ & -49.01 & 19.57 & 0.59 & $5.44 \times 10^{-4}$ & $2.04 \times 10^{-6}$ & 96.01 \\
\hline & $0.5-1$ & 19.57 & $1.49 \times 10^{-5}$ & -70.60 & 19.57 & 0.64 & $8.37 \times 10^{-4}$ & $2.00 \times 10^{-6}$ & 95.59 \\
\hline & $1-3$ & 19.57 & $8.09 \times 10^{-6}$ & -76.39 & 19.57 & 0.73 & $5.87 \times 10^{-4}$ & $1.11 \times 10^{-6}$ & 94.68 \\
\hline \multirow{3}{*}{ ZG } & $0.2-0.25$ & 23.49 & $2.33 \times 10^{-5}$ & 46.95 & 23.49 & 0.48 & $1.70 \times 10^{-4}$ & $1.57 \times 10^{-6}$ & 98.55 \\
\hline & $0.5-1$ & 23.49 & $1.25 \times 10^{-5}$ & 79.97 & 23.49 & 0.55 & $7.84 \times 10^{-5}$ & $1.15 \times 10^{-6}$ & 98.73 \\
\hline & $1-3$ & 23.49 & $4.61 \times 10^{-6}$ & 92.78 & 23.49 & 0.70 & $3.21 \times 10^{-5}$ & $9.60 \times 10^{-7}$ & 97.10 \\
\hline
\end{tabular}

\section{Discussion}

Although JLS coal contains more vitrinite and less inertinite compared to ZG coal, its diffusivity is greater. This contradicts current knowledge, in which vitrinite is more microporous and has a smaller diffusivity compared to inertinite [30,31]. This anomalous phenomenon may be due to the different structures of the two coals. ZG coal is hard while JLS coal is brittle and easy to grind. The brittle structure of JLS coal increases its abundance of macropores from grinding relative to ZG coal, imparting greater diffusivity to the crushed JLS coal than the crushed ZG coal. The increased macropore content due to grinding also reduces the adsorption capacity of the JLS coal, which may indicate that the adsorption capacity and desorption efficiency are somewhat inversely correlated. Macropores favor diffusion but diminish adsorption capacity, whereas micropores facilitate adsorption but are detrimental to diffusion. Therefore, when designing CBM or ECBM projects, the pore distribution in the coal should also be considered as an influential factor.

The reduction of diffusivity in the ZG coal with increasing particle size may be due to a larger particle-size-induced diffusion path, which requires a longer passage time. Coals with fine particles can achieve complete desorption more quickly and desorb more $\mathrm{CH}_{4}$ in the same period, as compared to coals with coarse particles. This is important for $\mathrm{CBM}$ recovery. As $\mathrm{CBM}$ production proceeds, $\mathrm{CH}_{4}$ desorbs and diffuses through the pore system to the cleats, and then migrates into the well or borehole. Since the desorption time is negligible $[8,30]$, CBM production efficiency is determined by the diffusion in the pore system and laminar flow in the cleat system. The former is controlled by the diffusivity and the latter by the permeability. Hydraulic fracturing is normally used to accelerate CBM production. This technique not only can increase permeability but also diffusivity by cracking the coalbed and reducing the path for diffusion.

\section{Conclusions}

This paper presents a series of results for modeling diffusion kinetics during the $\mathrm{CH}_{4}$ desorption process in two Chinese coals with different particle sizes. The UP model failed to describe the experimental measurements while the BD model agreed well with the data and was consistent with the findings of many other works. The relationship between diffusivity and particle size was different for the two coals. For the hard ZG coal, diffusivity for both macropores and micropores decreased with increasing particle size. In contrast, for the brittle JLS coal, micropore diffusivity decreased but macropore diffusivity varied somewhat stochastically as the particle size increased. These disparate trends may be due to the different coal structures, such that the correlation between diffusivity and particle size may be coal-dependent and no universal relationship can be found between them.

Coal structure has a significant impact on the diffusivity of a coal sample. The higher vitrinite content of JLS coal suggests that its diffusivity should be greater than that of ZG coal. In reality, the situation is the reverse. The brittle structure of JLS coal resulted in a greater degree of macropore generation during grinding than the hard ZG coal, resulting in the greater diffusivity of the former than the latter crushed coal. The grinding-generated macropores also reduced the adsorption capacity of JLS coal. This may indicate that the properties of adsorption capacity and desorption efficiency are somewhat inversely correlated. Macropores favor diffusion but diminish adsorption capacity, while 
micropores facilitate adsorption but are harmful for diffusion. Therefore, when designing CBM or ECBM projects, the pore distribution in the coal should also be considered as an influential factor.

The reduction in diffusivity of the ZG coal with increasing particle size indicates that coals with fine particles can complete desorption more quickly and desorb more $\mathrm{CH}_{4}$ in the same period, as compared to coals with coarse particles. This is important for CBM recovery. Since the desorption time is negligible, the CBM production efficiency is determined by diffusion in the pore system and laminar flow in the cleat system. The former is controlled by the diffusivity and the latter by the permeability. Hydraulic fracturing is normally used to accelerate CBM production. This technique can increase both the permeability and diffusivity by cracking the coalbed and reducing the path for diffusion.

Author Contributions: Conceptualization, J.Z.; methodology, J.Z.; validation, J.Z.; writing-original draft preparation, J.Z.; writing-review and editing, J.Z. and K.W.; visualization, J.Z.; funding acquisition, J.Z. and Y.Y. All authors have read and agreed to the published version of the manuscript.

Funding: This research was funded by the National Natural Science Foundation of China (51804312; 51704184; 51874314) and the State Key Laboratory Cultivation Base for Gas Geology and Gas Control (WS2019A03).

Acknowledgments: The first author (Jie Zang) acknowledges Wenjuan Song for her support and devotion in the past decade.

Conflicts of Interest: The authors declare no conflict of interest.

\section{Nomenclature}

C Sorbate concentration in whole particle in the UP model, $\mathrm{mol} \cdot \mathrm{m}^{-3}$

$C_{a} \quad$ Sorbate concentration in macropores in the BD model, $\mathrm{mol} \cdot \mathrm{m}^{-3}$

$C_{i} \quad$ Sorbate concentration in micropores in the BD model, $\mathrm{mol} \cdot \mathrm{m}^{-3}$

$\mathrm{C}_{s a} \quad$ Sorbate concentration on macropore surfaces in the BD model, $\mathrm{mol} \cdot \mathrm{m}^{-2}$

$C_{s i} \quad$ Sorbate concentration on micropore surfaces in the BD model, $\mathrm{mol} \cdot \mathrm{m}^{-2}$

$D_{a} \quad$ Macropore diffusion coefficient in the BD model, $\mathrm{m}^{2} \cdot \mathrm{s}^{-1}$

$D_{a}^{\prime} \quad$ Effective macropore diffusivity in the BD model, $\mathrm{s}^{-1}$

$D_{e} \quad$ Effective diffusivity in the UP model, $\mathrm{s}^{-1}$

$D_{i} \quad$ Micropore diffusion coefficient in the BD model, $\mathrm{m}^{2} \cdot \mathrm{s}^{-1}$

$D_{i}^{\prime} \quad$ Effective micropore diffusivity in the BD model, $\mathrm{s}^{-1}$

$D_{u} \quad$ Diffusion coefficient in the UP model $1, \mathrm{~m}^{2} \cdot \mathrm{s}^{-1}$

$D_{u}^{\prime} \quad$ Effective unipore diffusivity in the UP model, $\mathrm{s}^{-1}$

$H_{a} \quad$ Henry constant in the BD model, $\mathrm{m}^{3} \cdot \mathrm{m}^{-2}$

$M_{0} \quad$ Initial sorption amount, mol

$M_{t} \quad$ Sorption amount at time $t$, mol

$M_{\infty} \quad$ Sorption amount at infinite time, mol

$P_{\infty} \quad$ Final gas pressure, $\mathrm{MPa}$

$R \quad$ Particle radius in the UP model, $\mathrm{m}$

$R_{a} \quad$ Macropore radius, $\mathrm{m}$

$R_{i} \quad$ Microsphere radius, $\mathrm{m}$

$S_{a} \quad$ Macropore surface area, $\mathrm{m}^{2}$

$T \quad$ Temperature, $\mathrm{K}$

$V_{a t} \quad$ total desorbed volume in the macropores at time $t, \mathrm{~m}^{3}$

$V_{a \infty} \quad$ total desorbed volume in the macropores, $\mathrm{m}^{3}$

$V_{i t} \quad$ total desorbed volume in the micropores at time $t, \mathrm{~m}^{3}$

$V_{i \infty} \quad$ total desorbed volume in the micropores, $\mathrm{m}^{3}$

$V_{t} \quad$ Total volume diffusing through the coal particles in time $t, \mathrm{~m}^{3}$

$V_{\infty} \quad$ Total desorbed volume at normal temperature-pressure (NTP, 273.15 K and $101325 \mathrm{~Pa}$ ), $\mathrm{m}^{3}$

$\alpha \quad$ Ratio of effective micropore diffusivity to equivalent macropore diffusivity, fraction

$\phi_{a} \quad$ Macroporosity in the BD model, fraction

$\phi_{i} \quad$ Microporosity in the BD model, fraction 


\section{References}

1. Busch, A.; Gensterblum, Y. CBM and $\mathrm{CO}_{2}-\mathrm{ECBM}$ related sorption processes in coal: A review. Int. J. Coal Geol. 2011, 87, 49-71. [CrossRef]

2. Bustin, R.; Clarkson, C. Geological controls on coalbed methane reservoir capacity and gas content. Int. J. Coal Geol. 1998, 38, 3-26. [CrossRef]

3. Bodden, W.R.; Ehrlich, R. Permeability of coals and characteristics of desorption tests: Implications for coalbed methane production. Int. J. Coal Geol. 1998, 35, 333-347. [CrossRef]

4. Li, D.Y.; Liu, Q.F.; Weniger, P.; Gensterblum, Y.; Busch, A.; Krooss, B. High-pressure sorption isotherms and sorption kinetics of $\mathrm{CH}_{4}$ and $\mathrm{CO}_{2}$ on coals. Fuel 2010, 89, 569-580. [CrossRef]

5. Cui, X.J.; Bustin, R.; Dipple, G. Selective transport of $\mathrm{CO}_{2}, \mathrm{CH}_{4}$, and $\mathrm{N}_{2}$ in coals: Insights from modeling of experimental gas adsorption data. Fuel 2004, 83, 293-303. [CrossRef]

6. Busch, A.; Gensterblum, Y.; Krooss, B.; Siemons, N. Investigation of high-pressure selective adsorption/desorption behaviour of $\mathrm{CO}_{2}$ and $\mathrm{CH} 4$ on coals: An experimental study. Int. J. Coal Geol. 2006, 66, 53-68. [CrossRef]

7. Majewska, Z.; Ceglarska-Stefańska, G.; Majewski, S.; Ziętek, J. Binary gas sorption/desorption experiments on a bituminous coal: Simultaneous measurements on sorption kinetics, volumetric strain and acoustic emission. Int. J. Coal Geol. 2009, 77, 90-102. [CrossRef]

8. Smith, D.M.; Williams, F.L. Diffusion models for gas production from coal: Determination of diffusion parameters. Fuel 1984, 63, 256-261. [CrossRef]

9. Pan, Z.J.; Connell, L. Modelling permeability for coal reservoirs: A review of analytical models and testing data. Int. J. Coal Geol. 2012, 92, 1-44. [CrossRef]

10. Liu, J.S.; Chen, Z.W.; Elsworth, D.; Qu, H.Y.; Chen, D. Interactions of multiple processes during CBM extraction: A critical review. Int. J. Coal Geol. 2011, 87, 175-189. [CrossRef]

11. Crank, J. The Mathematics of Diffusion; Clarendon Press: Oxford, UK, 1975.

12. Ruckenstein, E.; Vaidyanathan, A.; Youngquist, G. Sorption by solids with bidisperse pore structures. Chem. Eng. Sci. 1971, 26, 1305-1318. [CrossRef]

13. Pan, Z.J.; Connell, L.; Camilleri, M.; Connelly, L. Effects of matrix moisture on gas diffusion and flow in coal. Fuel 2010, 89, 3207-3217. [CrossRef]

14. Laxminarayana, C.; Crosdale, P. Controls on methane sorption capacity of Indian coals. AAPG Bull. 2002, 86, 201-212.

15. Laxminarayana, C.; Crosdale, P. Role of coal type and rank on methane sorption characteristics of Bowen Basin, Australia coals. Int. J. Coal Geol. 1999, 40, 309-325. [CrossRef]

16. Švábová, M.; Weishauptová, Z.; Přibyl, O. The effect of moisture on the sorption process of $\mathrm{CO}_{2}$ on coal. Fuel 2012, 92, 187-196. [CrossRef]

17. Staib, G.; Sakurovs, R.; Gray, E. A pressure and concentration dependence of $\mathrm{CO}_{2}$ diffusion in two Australian bituminous coals. Int. J. Coal Geol. 2013, 116-117, 106-116. [CrossRef]

18. Pillalamarry, M.; Harpalani, S.; Liu, S. Gas diffusion behavior of coal and its impact on production from coalbed methane reservoirs. Int. J. Coal Geol. 2011, 86, 342-348. [CrossRef]

19. Charrière, D.; Pokryszka, Z.; Behra, P. Effect of pressure and temperature on diffusion of $\mathrm{CO}_{2}$ and $\mathrm{CH}_{4}$ into coal from the Lorraine basin (France). Int. J. Coal Geol. 2010, 81, 373-380. [CrossRef]

20. Clarkson, C.; Bustin, R. The effect of pore structure and gas pressure upon the transport properties of coal: A laboratory and modeling study. 2. Adsorption rate modeling. Fuel 1999, 78, 1345-1362. [CrossRef]

21. Marecka, A.; Mianowski, A. Kinetics of $\mathrm{CO}_{2}$ and $\mathrm{CH}_{4}$ sorption on high rank coal at ambient temperatures. Fuel 1998, 77, 1691-1696. [CrossRef]

22. Busch, A.; Gensterblum, Y.; Krooss, B.; Littke, R. Methane and carbon dioxide adsorption-diffusion experiments on coal: Upscaling and modeling. Int. J. Coal Geol. 2004, 60, 151-168. [CrossRef]

23. Gruszkiewicz, M.; Naney, M.; Blencoe, J.; Cole, D.; Pashin, J.; Carroll, R. Adsorption kinetics of $\mathrm{CO}_{2}, \mathrm{CH}_{4}$, and their equimolar mixture on coal from the Black Warrior Basin, West-Central Alabama. Int. J. Coal Geol. 2009, 77, 23-33. [CrossRef]

24. Bhowmik, S.; Dutta, P. Adsorption rate characteristics of methane and $\mathrm{CO}_{2}$ in coal samples from Raniganj and Jharia coalfields of India. Int. J. Coal Geol. 2013, 113, 50-59. [CrossRef] 
25. Han, F.S.; Busch, A.; Krooss, B.; Liu, Z.Y.; Yang, J.L. $\mathrm{CH}_{4}$ and $\mathrm{CO}_{2}$ sorption isotherms and kinetics for different size fractions of two coals. Fuel 2013, 108, 137-142. [CrossRef]

26. Nandi, S.P.; Walker, J.; Philip, L. Activated diffusion of methane from coals at elevated pressures. Fuel 1975, 54, 81-86. [CrossRef]

27. Siemons, N.; Busch, A.; Bruining, H.; Krooss, B.; Gensterblum, Y. Assessing the kinetics and capacity of gas adsorption in coals by a combined adsorption/diffusion method. In SPE Annual Technical Conference and Exhibition; Society of Petroleum Engineers: Denver, CO, USA, 2003; pp. 5-8.

28. Wang, K.; Zang, J.; Feng, Y.; Wu, Y. Effects of moisture on diffusion kinetics in Chinese coals during methane desorption. J. Nat. Gas Sci. Eng. 2014, 21, 1005-1014. [CrossRef]

29. Smith, D.M.; Williams, F.L. Diffusion models for gas production from coals: Application to methane content determination. Fuel 1984, 63, 251-255. [CrossRef]

30. Crosdale, P.; Beamish, B.; Valix, M. Coalbed methane sorption related to coal composition. Int. J. Coal Geol. 1998, 35, 147-158. [CrossRef]

31. Chalmers, G.; Bustin, M. On the effects of petrographic composition on coalbed methane sorption. Int. J. Coal Geol. 2007, 69, 288-304. [CrossRef]

(C) 2020 by the authors. Licensee MDPI, Basel, Switzerland. This article is an open access article distributed under the terms and conditions of the Creative Commons Attribution (CC BY) license (http://creativecommons.org/licenses/by/4.0/). 